\title{
SCUDS, SHELTERS AND RETREATING SOLDIERS: THE LAWS OF AERIAL BOMBARDMENT IN THE GULF WAR
}

\author{
PETER BARBER*
}

\begin{abstract}
The author looks at whether laws governing war can ever reduce suffering by imposing restrictions on the methods and means of waging war. In particular, the laws of war have tended either to address past technology or to fall victim to the exigencies of war. The author first discusses, without deciding, whether there can be any moral grounding for laws regulating war. Next, he examines the development of laws governing aerial bombardment. Pertinent international laws, protocols and conventions are canvassed. Finally, the efficacy of the laws of aerial bombardment are assessed within the context of three specific events during the Gulf War. The author evaluates whether combatants in the Gulf War adhered to the laws governing aerial bombardment; he concludes that the stronger party's conduct during the Gulf War substantially complied with these restrictions. Such adherence in itself constitutes a law-making function. Thus, although the enforceability of laws restricting war is arguable, the body of law itself can have the limiting effect intended.
\end{abstract}

L'auteur se demande si le droit de la guerre pourrait éventuellement diminuer les souffrances en imposant des restrictions sur les moyens guerriers. Plus précisément, les lois dans ce domaine tendent à se rapporter à la technologie ancienne ou à succomber aux exigences de la guerre. L'auteur examine d'abord, sans se prononcer, si les lois qui régissent la guerre peuvent être fondées sur un ordre moral quelconque. II étudie ensuite l'évolution des lois qui régissent les bombardements aériens et passe en revue les lois, les conventions et les protocoles internationaux pertinents. Finalement, il évalue l'efficacité des lois en question dans le contexte de trois événements précis survenus pendant la guerre du Golfe. L'auteur examine si les combattants ont respecté les lois régissant les bombardements aériens; il conclut que le comportement du camp le plus fort était essentiellement conforme aux restrictions. Une telle adhésion constitue en ellemême une fonction normative. Ainsi, bien que le caractère exécutoire des lois limitant les guerres puisse être remis en question. le droit en soi peut avoir l'effet restrictif visé.

\section{TABLE OF CONTENTS}

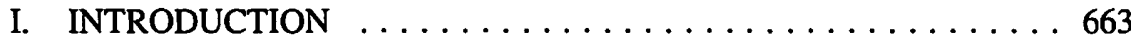

II. MORAL THEORY AND THE LAWS OF WAR $\ldots \ldots \ldots \ldots 665$

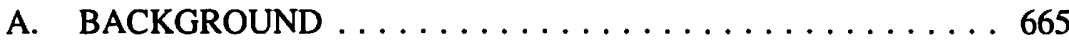

III. THE PURPOSES OF THE LAWS OF WAR $\ldots \ldots \ldots \ldots \ldots \ldots 66$

IV. THE ENFORCEMENT PROBLEM $\ldots \ldots \ldots \ldots \ldots \ldots \ldots \ldots 68$

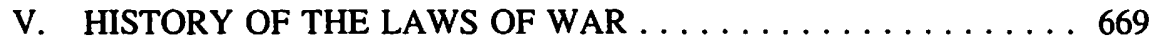

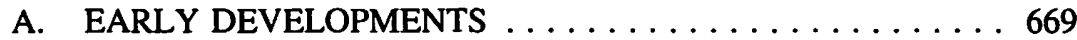

B. THE NINETEENTH CENTURY $\ldots \ldots \ldots \ldots \ldots \ldots \ldots 671$

C. THE TWENTIETH CENTURY $\ldots \ldots \ldots \ldots \ldots \ldots \ldots 674$

D. POST WORLD WAR II $\ldots \ldots \ldots \ldots \ldots \ldots \ldots \ldots 676$

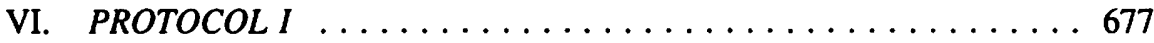

VII. STATUS OF PROTOCOL $I \ldots \ldots \ldots \ldots \ldots \ldots \ldots \ldots 63$

VIII. APPLICATION TO THE GULF WAR $\ldots \ldots \ldots \ldots \ldots \ldots \ldots 685$

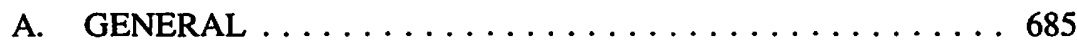

B. THE SCUD ATTACKS $\ldots \ldots \ldots \ldots \ldots \ldots \ldots \ldots 66$

C. THE AMIRIYA BOMB SHELTER $\ldots \ldots \ldots \ldots \ldots \ldots 68$

D. RETREATING SOLDIERS $\ldots \ldots \ldots \ldots \ldots \ldots \ldots \ldots 69$

This article reflects the views of the author only. Captain Peter Barber is currently a legal officer serving with the Judge Advocate General of the Canadian Forces. 


\section{INTRODUCTION}

It is one of the sad ironies of the human condition that as the laws of war have evolved placing an ever greater emphasis on the protection of basic human rights, so too has the scope of war widened. Allied with weapons of catastrophic destructive power, this has resulted in ever higher numbers of victims of war and in particular a higher proportion of innocent victims.' Such an observation could easily lead to skepticism about the moral worth or practicality of the laws of war yet it must be remembered that many factors, like nationalism, industrialization, and religion, contribute to the commencement and conduct of war. In comparison, the laws of war have usually played a relatively minor but not altogether insignificant role in the history of warfare. It must also be remembered that assessment of the value of rules in warfare is difficult because there is no way of knowing what war would have been like absent some or all constraints.

A more recent criticism of the laws of war concerns the relevance of the laws to modern war; too often laws are designed to cure the worst horrors of the last war. ${ }^{2}$ In an age of rapidly changing technology, particularly the technology of weaponry, it is important that laws have a progressive potential. At the same time, laws that express overly broad principles risk self-serving interpretation or ambiguity, both of which would render the law meaningless. Despite these apparently irreconcilable differences, a sufficient number of countries and international organizations have felt that the revision of the laws of war is of sufficient importance to warrant continued negotiations. This consensus led, in 1977, to the formulation of two protocols additional to the Geneva Conventions, $1949 .^{3}$

This article examines the status of the first, Protocol $I$, in public international law concentrating on its application to three specific incidents in the Gulf War to determine if the most recent attempt to resolve some of the traditional problems associated with the laws of war has been successful. The three incidents chosen have as a common denominator contentious aspects of aerial bombardment: the use by Iraq of long range missiles to attack Israel, the killing of civilians in a Baghdad shelter by U.S. bombs, and the bombardment of soldiers in full retreat from the battlefield.

Recent events in the Persian Gulf shattered much of the euphoria that followed the end of the Cold War. It seemed for a short time that man had rejected war as a method of solving differences. The Iraqi invasion of Kuwait on August 2, 1990 came as a painful

H. Blix, "Area Bombardment: Rules and Reasons" (1978) 49 B.Y.I.L. 31 at 31.

See, for example, the comments of J. Schell in E. Knoll \& J. Nies McFadden, eds., War Crimes and the American Conscience (New York: Holt, Rinehart and Winston, 1970) at 67 where he states, "Much of the lawlessness in Vietnam occurs because the laws, or the orders handed down, have so little application to the situation the men actually face in the field."

3 These are formally entitled: Protocol Additional to the Geneva Conventions of 12 August, 1949, and Relating to the Protection of Victims of International Conflict [hereinafter Protocol I] and Protocol Additional to the Geneva Conventions of 12 August 1949, and Relating to the Protection of Victims of Non-International Conflict [hereinafter Protocol II] 1125 U.N.T.S. 17512. 
reminder that there was still a long way to go before the world would be free of war. With the commencement of a massive bombing campaign by countries of the United Nations in a coalition aimed at removing Iraqi forces from Kuwait, world attention became focused in an unprecedented manner on the effects of modern weaponry unleashed on a country. For the first time, people around the world could watch war unfolding on their televisions as it happened; cruise missiles could be seen as they flew down Baghdad streets toward their targets while the night sky was lit up with anti-aircraft fire. With the depth of coverage available to the citizen in the street, notwithstanding extensive censorship by both parties, the battle for public opinion became an essential part of war strategy. For the United Nations coalition in particular, it was imperative that the war be conducted in as scrupulous a manner as possible; any deviations from internationally recognized norms could have been fatal to maintaining a fragile alliance and retaining the support of a hesitant public. It is necessary then to consider how effectively those norms have been manifested legally both from the practical perspective of how they can be seen to have guided the conduct of the war and whether or not they are morally coherent.

Law and warfare at best form an uncomfortable alliance. War appears at first blush to be an activity devoid of moral content. To formulate laws to regulate an inherently immoral activity seems a contradictory or self-defeating activity. The history of the laws of war is one of mixed success with the skeptical saying only those laws that are either meaningless or do not harm a party's capacity to wage war are ever agreed to or acted upon. Thus we find global consensus that barbed spear and arrow tips are illegitimate weapons while nuclear warheads have not been formally prohibited. ${ }^{4}$ In order to understand these and other anomalies regarding the laws of war, I shall first try to provide a moral framework by which the laws can best be understood. This approach will make it possible to measure the success of the laws in a specific context. In addition to having a moral framework, it is helpful in understanding the laws of war to see how they have developed over time.

After having established a moral and historical context for understanding the laws of war, particularly those regarding aerial bombardment, it will then be possible to examine the status of those laws today. This will involve discussing both the formal degree of acceptance of the latest attempts to codify laws of war by various nations and whether de facto observance is sufficient to constitute the laws as part of customary international law.

After laying this foundation, I will then apply the current law to the events described. In so doing, important questions will inevitably arise. Is there any way these laws can be enforced against either side? Do problems enforcing the laws render them meaningless? Do the laws favour the wealthy, powerful, and technologically advanced party in a conflict? Can laws be developed for application in an asymmetric conflict with any hope that the weaker party will follow them? It is hoped that in the course of the following 
examination, some answers to these questions, ones that have long plagued the drafters of the laws of war, can be found.

\section{MORAL THEORY AND THE LAWS OF WAR}

\section{A. BACKGROUND}

It is common to characterize war as the breakdown of all norms of civilized behaviour, as a time when all rules have been forsaken. War constitutes one party attempting to deny to another party its sovereignty and rights; a time when one party tries to impose its will on another by the use of force. ${ }^{5}$ If it is granted that morality provides a framework for the rules that regulate society, and the fundamental characteristic of war is the denial of those very rules, it follows that war is immoral. In addition to being an activity that, as a whole, is outside morality, it also invariably has internal features that make it immoral even when it does not completely deny societal rules, if that is possible. Minimally, our vast collective experience of war demonstrates that war inevitably involves the killing of innocent people, regardless of how narrowly one chooses to construe the term "innocent": 6

The principle wickedness which is a temptation to those engaged in warfare is the killing of the innocent, which may often be done with impunity and even the glory of those who do it.

It is well known by those who enter war that these deaths will occur, so even if they are not intentionally done, their foreseeability renders all participants complicit. ${ }^{7}$ The foreseeability of killing innocents, although not peculiar to air war, for it has been occurring at least as long as war has been recorded, has been a particularly pronounced aspect of warfare since aerial bombardment came into its own during World War Two: ${ }^{8}$

Here, indeed lies the crux of the matter; the development of air warfare has brought this essential change that the civilian population is now suffering from the scourge of war in a measure out of comparison greater than ever before.

Thus, as G.E.M. Anscombe puts it, ${ }^{9}$ for many, war is characterized by the "extraordinary occasions it offers for viciously unjust proceedings on the part of military commanders and warring governments, which at the time attract praise and not blame from their people." The place for rules in such conduct seems not only contradictory to morality but may even give a patina of legitimacy to it.

G. Adler, "Targets in War: Legal Considerations" in R.A. Falk, ed., The Vietnam War and International Law, Vol. 3 (Princeton: Princeton University Press, 1972) 281 at 282-83.

- G.E.M. Anscombe, "War and Murder" in J. Rachels, ed., Moral Problems (New York: Harper and Rowe, 1971) 285 at 287.

7 R. Wasserstrom, "On the Morality of War: A Preliminary Inquiry" in ibid. 298 at 331. Anscombe, ibid., holds the opposite view and ties culpability to Christian notions of intent that exclude from culpability mere foreseeability, see page 293. 
In addition to the problems of the institutional morality of war and the morality of conduct necessarily attendant upon war referred to above, it is also problematic whether the conduct of nations can be assessed in moral terms. Can a nation, for example, be said to have intentions or foreseeability in the same way we relate those concepts to the behaviour of individuals? ${ }^{10}$ These sorts of problems associated with an assessment of the morality of war, and, by extension, to the relevance of having rules governing wars, leads to the notion that the law of war is at the least irrelevant, and at worst, immoral:"

First, a skepticism as to the meaningfulness of any morality within war is extremely common. The gnomic statement is Sherman's: "War is hell." The fuller argument depends upon a rejection of the notion of war as a game. It goes something like this, War is the antithesis of law of rules. It is violence, killing and all of the horror they imply. Even if moral distinctions can be made in respect of such things as the initiation and purposes of a war, it is absurd to suppose that moral distinctions can be drawn once a war has begun. All killing is bad, all destruction equally wanton.

\section{: \\ III. THE PURPOSES OF THE LAWS OF WAR}

The laws of war can be divided between two general categories: those concerned with the right to resort to war called jus ad bellum and those concerned with permissible conduct during war known as jus in bello. It is the latter category that is of interest to this study. Given the apparent paradox of rules in warfare, one must first look to what the laws of war are actually designed to achieve. It is not the goal of the laws of war to render war a humane institution; ${ }^{12}$ this by definition would be impossible and make the laws susceptible to the arguments posited above. However, because war itself may be immoral $^{13}$ does not mean that conduct within war cannot be distinguished on the basis of morality or that differing degrees of reprehensibility cannot be assigned to conduct within war. To hold otherwise amounts to a position of what Wasserstrom calls "moral nihilism." ${ }^{14}$ The main goal of the laws of war can be simply stated as the reduction of suffering by prohibiting certain methods and means of waging war. ${ }^{15}$

This goal can be seen to serve several purposes. First, utilitarian arguments propose a sort of Kantian categorical imperative as shaping the laws. It is to the long term benefit of both sides to a conflict to conduct themselves in a manner similar to how they would wish to be treated, for any violations of acceptable conduct by one side will inevitably be reciprocated. ${ }^{16}$ Furthermore, conduct in excess of what is required to achieve either the immediate tactical or long-range strategic goals will often be counterproductive: ${ }^{.7}$

Wasserstrom, supra note 7 at 300 .

lbid. at 316.

B.V.A. Roling, "The Significance of the Laws of War" in A. Cassesse, ed., Current Problems of International Law: Essays on U.N. Law and the Law of Armed Conflict (Milano: Dott A. Giuffre Editore, 1975) 133 at 154.

I leave this undecided.

See generally Wasserstrom, supra note 7.

Roling, supra note 12 at 154.

R.B. Brandt, "Utilitarianism and the Rules of Law" in M. Cohen et al., eds., War and Moral Responsibility (Princeton: Princeton University Press, 1974) 25 at 40.

Adler, supra note 5 at 321. 
The truth that moderation in war will deprive an enemy of a great weapon, despair, has been recognized for centuries.

For example, the area bombing campaigns undertaken by both Allied and Axis powers in World War Two wreaked tremendous destruction and caused huge numbers of civilian deaths. Yet rather than undermining morale, the campaigns may well have strengthened the resolve of those targeted. ${ }^{18}$ Given the uncertain advantages gained from area bombing of civilians and the known cost, the U.S. saturation bombing of North Vietnam could not be supported by utilitarian considerations. ${ }^{19}$

Second, the rules of warfare are important not only to diminish the suffering of the victims but also to preserve the humanity of the participants as far as possible given the horrendous nature of their task. Those who are called on to wage war rarely have any influence over the commencement of war, yet it is these participants who suffer the greatest psychological trauma and risk of physical injury. After the cessation of hostilities, these participants must once again become contributing members to a society that is predicated on observance of the rule of law. A system of rules that provides some guidance amidst the chaos of war preserves to a certain extent a modicum of humanity in those called on to perform acts that under normal peacetime conditions would be considered among the most heinous. By restricting the conditions under which one person can take another's life, at least some respect for human life can be maintained. ${ }^{20}$ The importance of this purpose can be seen in the tragic circumstances surrounding the massacre of 488 civilians including pregnant women, the old, and infants at My Lai by U.S. soldiers during the Vietnam war. It is generally conceded that in that specific instance, and perhaps throughout much of the U.S. forces during that war, there was insufficient understanding of what sorts of conduct were impermissible even in wartime. ${ }^{21}$ Quite apart from the tragic consequences for the victims and survivors of the village of My Lai, the participants have suffered devastating personal scars, ${ }^{22}$ and it remains a black mark on the conscience of a country that places a premium on respect for the dignity of human life.

In addition to attempting to diminish suffering in war as much as possible and preserving the humanity of the participants, Roling identifies two factors related to each

The atomic bombs dropped on Hiroshima and Nagasaki provide stark exceptions to this lesson. Brandt, supra note 16 at 39.

Roling, supra note 12 at 154 . He goes further to suggest this preservation of respect for human life is essential to the preservation of a nation's cultural identity and thus its very essence. For if a nation permits unrestricted killing, then its cultural life may be destroyed by the disappearance of values. This may in fact have happened in Cambodia where, despite the auto-genocidal practices of the Khmer Rouge under Pol Pot, they remain a potent military and political force.

See T. Taylor, Nuremberg and Vietnam: An American Tragedy (Chicago: Quadrangle Books, 1970) for a good description of the My Lai massacre by a participant in the Nuremberg tribunals. Also, for graphic descriptions of some of the more extreme behaviour during that war, see M. Herr, Dispatches (New York: Alfred A. Knopf Inc., 1977) and Knoll \& McFadden, supra note 2 for discussion of the general breakdown of the distinction between permissible and impermissible conduct. available from PBS. 
other as important purposes of the laws of war: ${ }^{23}$ to decrease the threat to the survival of civilization and to have a favourable impact on the development of new weapons. The worthiness of the first can hardly be questioned; difficulties associated with the second deserve brief mention. Laws have been notoriously ineffective in preventing the proliferation of nuclear weapons, potentially the most devastating weapons in the human arsenal. However, following extensive use of poisonous gas during World War One, the Protocol for the Prohibition of the Use of Asphyxiating, Poisonous or Other Gases, and of Bacteriological Methods of Warfare, signed in Geneva in 1925 by most of the countries of the world, ${ }^{24}$ has been observed in most conflicts since. This would tend to demonstrate that the laws of war have at least the potential to limit the means and methods by which warfare is conducted. ${ }^{25}$

\section{THE ENFORCEMENT PROBLEM}

It has been seen thus far that the laws of war have, at least arguably, a moral framework from which to gain coherence. Further, they serve at least four important purposes. The discussion of the last mentioned purpose contains hints of the main problem associated with the laws of war: the lack of any means of enforcement. Of what effect, and therefore of what importance, can laws be if they cannot be enforced? "If law is indeed that which courts are prepared to enforce, then the status of the law of war is weak. ${ }^{26}$ Going even further, many contend that a law without an enforcement mechanism is an oxymoronic concept, for law implies a rule enforced by a sanction. ${ }^{27}$ It is not the purpose of this paper to delve deeply into the nature of law. However, as has been pointed out, there is a minimalist argument that provided we are no worse off with the laws and possibly a little bit better off, they are worth preserving and developing. ${ }^{28}$

Perhaps more telling is the idea that lack of enforcement mechanisms is symptomatic of the state of the law's development, rather than a conceptual argument denying its merit: 29

International law is a body of law characteristic of an undeveloped community, lacking a central legislative body and a central power which is able to enforce the law. This lack of enforcement power is one of the characteristics of the law of nations, showing clearly its underdeveloped character.... It is in connection with the laws of war that the impossibility of enforcing the law is most striking.

23 Supra note 12 at 154 .

24 See Schindler \& Toman, eds., The Laws of Armed Conflicts (Leiden: A.W. Sijthoff, 1973) at 109.

25 It must be acknowledged that many factors contribute to the non-use of chemical and bacteriological weapons. Nevertheless, condemnation by most of the nations of the world through formulation of a positive law is not insignificant.

26 S. Levinson, "Responsibility for Crimes of War" in M. Cohen, supra note 16, 104 at 130.

27 See H.L.A. Hart, The Concept of Law (Oxford: Oxford University Press, 1961) for the most influential exposition of this principle since John Austin.

28 Roling, supra note 12 at 155.

29 B.V.A. Roling, "Aspects of the Criminal Responsibility for Violations of the Laws of War" in A. Cassesse, ed., The New Humanitarian Law of Armed Conflict (Napoli: Editoriale Scientifica, 1975) 199 at 199. 
If this viewpoint is correct, then laws of war as we know them now may be a necessary preliminary step to more effective prohibitions against the waging and conduct of war in the future. ${ }^{30}$ The enunciation of normative guidelines directed at the participants in war also serves another purpose. The norms expressed by the laws of war are not strictly for consumption by soldiers but, if carefully drafted, reflect communal understandings of what sort of conduct is acceptable. Given the hugely expanded role of the media in modern war, it is now open to a much larger segment of the community to form an opinion on the manner in which a war is being fought and the actual effects of war. ${ }^{31}$ Laws of war can thus provide a yardstick for the community to make judgments. Because media will be able to reach a wide audience from both sides of a conflict (as was the case in the Gulf War), it will not be enough for generals and politicians to claim adherence to the rules, for such a declaration if contradicted by news reports will be of greater damage than any limitations placed on operations by actual adherence to the rules. ${ }^{32}$ Neither should the importance of adverse publicity be underestimated, particularly in a democracy. Protesters during the Vietnam war gained considerable moral legitimacy from the reports coming out of the war and can be cited as an important factor in U.S. withdrawal from the conflict.

An analogy can be drawn between the roles of the laws of war and the criminal law. The deterrent value of criminal law would appear to be greater than that of the laws of war but given a philosophy that crimes and war are both a part of the human condition, then the true value of both is in their capacity to constitute and reflect community values. ${ }^{33}$ As will be seen with greater clarity when Protocol $I$ is examined, concepts fundamental to western criminal law like intent, foreseeability, and recklessness are important in the laws of war.

That the laws of war are yet imperfect is unquestionable. But the importance in moral terms of continuing their development and refinement can be seen not only from the purposes of the law, but also because of the nature of war itself: ${ }^{34}$

With growing facilities for achieving destruction in far away hinterlands the temptations to do so increase. Even very marginal gains may appear attractive if the costs are not too high or the resources for air war are abundant.

\section{HISTORY OF THE LAWS OF WAR}

\section{A. EARLY DEVELOPMENTS}

Although the destructive capacity of twentieth century weaponry is unprecedented, ferocity in war making and the abominable treatment of bystanders is not. While St. 
Augustine in the fourth century A.D. ${ }^{35}$ and Thomas Aquinas in Summa Theologica in the thirteenth century ${ }^{36}$ dealt in their writings with justification for waging war, ${ }^{37}$ one of the earliest examples of codification of acceptable conduct in war appears interestingly enough in the Koran. It is likely that many of the laws found in the Koran had their origin in tribal customs of hospitality, asylum, and vendetta that pre-dated Muhammad while others were peculiar to Islam. ${ }^{38}$ It is interesting to review some of these rules, both because of their relevance to the Gulf War and because they provide evidence of an early consensus between two distinct cultures regarding the laws of war. It is worth noting in passing that the doctrine of jihad, or holy war, which has suffered such a bad reputation with Westerners, is not far removed from the concept of just war which is so important in understanding western history. ${ }^{39}$ Also, although jihad's ostensible purpose is to spread Islam, it originally may have been conceived as a means of uniting the traditionally fratricidal Arab tribes. ${ }^{40}$

One of the primary rules developed in the Koran was a prohibition against any shedding of blood or destruction of property not necessary to the objective of the campaign. ${ }^{41}$ The concept of necessity was mirrored in later European writers and continues to be a foundational concept in modern laws of war. There was also a general prohibition against the slaying of women and children although this prohibition did not apply to polytheists. ${ }^{42}$ In addition to rules like the ones above that covered combatants and noncombatants alike, there were specific rules restricting conduct towards the enemy. It must have been of no small comfort to opposing soldiers that there was a prohibition against carrying the heads of those killed in battle on the ends of lances as well as any other mutilation of the dead, and a prohibition against the use of treachery to kill the enemy ${ }^{43}$ Of particular interest in the context of the Gulf War and the threatened use of chemical weapons was a prominent medieval Islamic jurist's interpretation that poisoned arrows in any form were not allowed. ${ }^{44}$

There was concurrent development in the western world as the medieval chivalric codes incorporated numerous concepts prohibiting the infliction of undue suffering. ${ }^{45}$ These concepts, in alliance with the philosophy of St. Augustine and Thomas Aquinas, resulted in significant scholarly commentary on the laws of war by Grotius and Gentili in the early

Taylor, supra note 21 at 59.

lbid. at 61.

Hence comes the concept of a "just war."

M. Khadduri, War and Peace in the Law of Islam (Baitimore: Johns Hopkins Press, 1955) at 21.

Since the Kellogg-Birand Pact in 1928 the doctrine of just war in western thought has been discredited as that agreement condemned aggressive war. It is interesting to note that President Bush frequently referred to the Gulf War as a "just war" in public statements, but it is not clear that he meant this in the legal sense.

Khadduri, supra note 38 at 102.

lbid. at 102.

Ibid. at 105. This exception provides some insight to the depth and vigour of the animosity between Muslims as monotheists and Hindus as polytheists. Polytheism is considerably more deviant in the Muslim hierarchy than alternative forms of monotheism like Christianity and so warrants more savage treatment. See ibid. at 74.

Ibid. at 104-08.

lbid. at 104.

Roling, supra note 12 at 140. 
sixteenth century and Vattel in the mid-seventeenth century. ${ }^{46}$ Although Grotius was prepared to admit that "...any thing done against an Enemy is lawful, ${ }^{47}$ the individual soldier did not have carte blanche: $:^{48}$

Yet if a Soldier, or any other Person, even in a just War, shall burn the Enemy's Houses, lay waste their Fields, and commit such other Acts of Hostility, without any Command, and besides when there is no necessity, or just Cause, in the Opinion of the Divines he stands obliged to make Satisfaction for those Damages. I have with reason added, what they have omitted, if there be not a just Cause, for if there be, he may perhaps be answerable for it to his own State, whose Orders he hath transgressed, but nor to his Enemy, to whom he hath done no Wrong.

Thus we see the concept of necessity, referred to earlier in the Koran as a limiting factor, emerging as an important idea in the European understanding of warfare. Vattel further clarified this concept: ${ }^{49}$

\footnotetext{
Necessity alone justifies Nations in going to war; and they should all refrain from, and as a matter of duty oppose, whatever tends to render war more disastrous.... All acts of hostility which injure the enemy without necessity, or which do not tend to procure victory, are unjustifiable, and as such condemned by the natural law.... On the other hand it [the Laws of Nations] permits or tolerates every act which in its essential nature is adapted to attaining the end of the war....
}

Thus Vattel took a highly practical view that implicitly acknowledged reality in warfare: a law that ignores entirely a commander's right to choose his method and means of obtaining his objective will only be honoured in the breach. The problem of reconciling military necessity with humanitarian concerns remains one of the main sources of disagreement between countries drafting new laws; drawing the fine line between these two opposing concepts is crucial to any successful humanitarian law of war. The idea espoused by Grotius and his colleagues that destruction in warfare should be limited to only that which is necessary and relevant to the goal of defeating the enemy will be seen to be of particular relevance to the rules of aerial bombardment. ${ }^{50}$

\section{B. THE NINETEENTH CENTURY}

The next significant developments occurred in the latter half of the nineteenth century. During the American Civil War, President Lincoln issued the Instructions for the Government of Armies of the United States in the Field, known as the Lieber Code after its drafter. ${ }^{51}$ The Lieber Code is significant because it represents "the first attempt to Law of War (New York: Transnational Publishers, 1985) 151 at 162-65. From De Jure Belli ac Pacis quoted in ibid. at 162.

Ibid. at 163.

From Le Droit des Gens, 1758, quoted in ibid. at 164.

Adler, supra note 5 at 296-97.

Schindler \& Toman, supra note 24 at 3. 
codify the laws of war. ${ }^{\text {"52 }}$ It reflects very clearly an understanding of the need for strict obedience by soldiers to martial law:

Art. 4. As martial law is executed by military force it is incumbent upon those who administer it to be strictly guided by the principles of justice honour and humanity... for the very reason that he [the soldier] possesses the power of his arms against the unarmed.

Articles 14 to 16, quoted in part, because of their influence in later developments of the laws of war discuss the concept of military necessity and merit: ${ }^{53}$

Art. 14. Military necessity... consists in the necessity of those measures which are indispensable for securing the ends of the war...

Art. 15. Military necessity admits of all direct destruction of life or limb of armed enemies, and of other persons whose destruction is incidentally unavoidable in the armed contests of war....

Art. 16. Military necessity does not admit of cruelty - that is, the infliction of suffering for the sake of suffering or for revenge, nor of maiming or wounding except in fight....

Subsequent articles recognized the sanctity of the non-combatant ${ }^{54}$ and the need to protect private, religious, and cultural property.$^{55}$ Article 19 compelled a commander to inform his enemy of imminent bombardment to allow for the evacuation of noncombatants with an exception being granted when surprise was necessary, presumably something easily justified by most commanders. Although military necessity was deemed to be of paramount importance, ${ }^{56}$ it is clear that only in the face of the most severe threat to the security of the nation would unlimited means of warfare be permissible. Also, a significant distinction is drawn between the combatant and non-combatant with greater protection afforded the latter than had hitherto been customary.

While the Lieber Code applied only to the Union Army, it provided a model for later attempts to reach international agreements. ${ }^{57}$ The St. Petersburg Declaration, 1868 , agreed to by all the major European powers, forbade the use of explosive bullets on the grounds that the suffering inflicted would be contrary to the laws of humanity. ${ }^{58}$ It therefore set a precedent for limiting the means of warfare and also for the potential of international agreement on the laws of war. A later attempt to reach a more comprehensive code failed at the Brussels Conference of $1874^{59}$ but, along with the independently produced Oxford Manual of $1880,{ }^{60}$ laid the groundwork for the Hague

Ibid.

lbid. at 6.

Art. 22 and 23, ibid. at 7.

Art. 34 to 38, ibid. at 8-9.

Art. 5, ibid. at 5.

Ibid. at 3.

Ibid. at 95-97.

Ibid. at 25-34.

lbid. at 35 . 
Conventions on Land Warfare of 1899 and $1907 .{ }^{61}$ Ratified by thirty-two countries including all of the major powers in the world, regulations attached to the later convention "...still constitute the most fundamental postulation of the laws of war that we have, especially with regard to the means and methods of warfare. ${ }^{.62}$ Most important among these rules is the principle laid down in Article 22, "The right of belligerents to adopt means of injuring the enemy is not unlimited." Article 23 goes on to list specific prohibitions against, among others, use of poisoned weapons, the killing of an enemy who has surrendered, declaring that no quarter will be given, and the use of arms calculated to cause unnecessary suffering. ${ }^{63}$

In addition, there are also specific regulations regarding bombardment similar in nature to those discussed in the Lieber Code. Article 25 reads, "The attack or bombardment, by whatever means, of towns, villages, dwellings, or buildings which are undefended is prohibited." Articles 26 and 27 go on to require the giving of warning, if possible, prior to attack and a duty to take all necessary steps to spare buildings of religious, cultural, or humanitarian significance. In the period between the two Hague conventions, the first flight of a heavier than air craft was made and hence the insertion in the later convention of the italicized words by whatever means. This article followed from an agreement reached earlier in 1907 called the Declarations on Projectiles from Balloons whereby it was stated that the signatories agreed to prohibit "the discharge of projectiles and explosives from balloons or by other new methods of a similar nature." ${ }^{164}$ The inclusion of "by whatever means" seemed to incorporate the above prohibition. Despite the apparent comprehensiveness of Article 25, the Conventions themselves were addressed to land warfare and so some uncertainty prevailed over whether naval bombardment was included. ${ }^{65}$ Consequently, a separate agreement was reached on naval bombardment that has been interpreted as applying also to bombardment from the air. The Convention on Bombardment by Naval Forces, 1907, in Article 1 prohibited the bombardment of undefended ports, towns, villages, dwellings or buildings. ${ }^{66}$ However, Article 2 has an important exception: ${ }^{67}$

Military works, military or naval establishments, depots of arms or war matérial, workshops or plant which could be utilized for the needs of the hostile fleet or army, and the ships of war in the harbour, are not, however, included in this prohibition.

This exception points to the difficulty of trying to promote humanitarian concerns while still recognizing the need to account for military necessity. In striving to find the balance, it would appear, at least in the cited example, that so broad an exception was created as to render the lofty principles of Article 1 void. At the opposite end of the spectrum, blanket prohibitions stood little chance of surviving under the terrible urgency that

Ibid. at 49-92.

L.C. Green, "Human Rights and the Law of Armed Conflict" in Green, supra note 46, 83 at 88. Schindler \& Toman, supra note 24 at 76-77.

lbid. at 134-35.

Ibid. at 591 .

Ibid. at 592.

Ibid. at 592. 
inevitably accompanies the outbreak of war. Nevertheless, these later nineteenth century codes are significant because they manifest widespread desire to constrain the destructive power developing at that time. Although imperfect in execution, they represent an important first step in reaching a consensus on principles of necessity guided by proportionality; the need to distinguish between those bearing arms (thus constituting an immediate threat) and the unarmed, and the need to protect various cultural, religious, and humanitarian institutions.

\section{THE TWENTIETH CENTURY}

Prior to World War One, fighting in war was largely confined to the vicinity of opposing armies and coastal towns. The advent of the airplane changed those limitations. Now combatants could reach far behind enemy lines to strike at the opponent's capacity to support a war and to undermine the will of the nation as a whole to fight. Although these attempts were mostly ineffective during World War I, the potential was clear. Shortly after the war, an attempt was made in the Hague Rules of Air Warfare to codify regulations respecting aerial bombardment and other aspects of warfare unique to the new invention. The rules were not ratified and so did not become legally binding, but they still contribute to the evolution of customary international law on the subject. ${ }^{68}$ Of particular interest to us are Articles 22 to 26 that deal with bombardment. ${ }^{69}$

Art. 22. Aerial bombardment for the purpose of terrorizing the civilian population, of destroying or damaging private property not of military character, or of injuring non-combatants is prohibited.

Article 24 provides further restrictions by making only military objectives, defined as those objects which constitute a distinct military advantage, legitimate targets. Furthermore, cities and towns not in the vicinity of land forces operations are not legitimate targets ${ }^{70}$ and even military installations and depots that cannot be bombed without an accompanying indiscriminate bombardment of the civilian population are prohibited targets. Commanders wishing to bombard cities and towns close to land operations must have a reasonably based presumption that the military concentration is sufficiently important to justify such bombardment. ${ }^{71}$ The important concept in these regulations is that there is a presumption against the military necessity of targets. It must be a distinct advantage militarily to the belligerent before he can bomb and even then there are certain comprehensive prohibitions. In fact, that terrorizing the population might reasonably or even certainly be presumed to be a distinct advantage is not sufficient to make it permissible conduct. This reverses the doctrine dating back at least to Grotius that anything that is militarily necessary is legitimate. ${ }^{72}$ The concept of proportionality is also developed in Articles 24(3) and 24(4) through prohibitions against bombing legitimate targets if indiscriminate bombing of civilians would result and through the need to assess the tactical value of a military target against the likelihood of harm to civilians. 
Given the uncertain potential of air warfare and a general reluctance to sacrifice sovereignty over a subject so intimately connected with self-defence, ${ }^{73}$ it is not surprising that the Hague Rules of Air Warfare, 1922 were not ratified. It was not long before the worst fears of the drafters would be realized. During the Italian invasion of Abyssinia in 1936, the Spanish Civil War, ${ }^{74}$ and Japanese attacks on Chaipei in 1932 and Nanking, Canton, and Hanbour in $1937,{ }^{75}$ the full horror of indiscriminate and terror motivated aerial bombardment was revealed. These bombardments were condemned by many nations but perhaps the most tragically portentous comment was made by a U.S. State Department spokesperson: ${ }^{76}$

This government has the view that any general bombing of an extensive area wherein resides a large populace engaged in peaceful pursuits is unwarranted and contrary to principles of law and humanity....

The League of Nations also adopted a declaration calling for immediate development of regulations restricting air warfare and avowing these principles: ${ }^{77}$

(1) The intentional bombing of civilian populations is illegal;

(2) Objectives aimed at from the air must be legitimate military objectives and must be identifiable; [and]

(3) Any attack on legitmate military objectives must be carried out in such a way that civilian populations in the neighbourhood are not bombed through negligence....

Made in 1938, the Declaration could not have had better timing nor demonstrated more clearly the ineffectiveness of that august body.

It is not necessary to go into detail regarding the events of World War II but certain points should be briefly mentioned. One of the characteristics distinguishing World War II from previous conflicts was the extent to which war was carried into the territory of the enemy. With huge armies, navies, and air forces using large amounts of sophisticated weaponry and consuming vast resources, the war effort became truly a national effort. Thus, there was logic behind striking deep into enemy territory for, by destroying industrial and transportation structures, the capacity of the enemy to wage war could be drastically reduced: ${ }^{78}$

As war becomes more totalitarian, however, civilians become less innocuous and the distinction disappears.... A simple condemnation of civilian targeting becomes unworkable when factory workers and peasants bear arms and tin buckets are as likely to be carrying fuel for trucks as water for children.... The

Factors that no doubt influence countries today when entering talks designed to reduce nuclear arsenals.

74

Immortalized in Picasso's famous painting Guernica.

Blix, supra note 1 at 35 .

Ibid. at 35.

Schindler \& Toman, supra note 24 at 154.

Adler, supra note 5 at 303. 
real problem is the marked change in civilian support of a war effort from the time of growing food and forging weapons.

The airplane provided the means for carrying out this goal. War became a total concept with the distinction between combatant and non-combatant blurring. But it was not the perfect means. Although it could yield tremendous military advantage, it could not do so with the sort of accuracy required for adherence to the Hague Rules of Air Warfare. ${ }^{79}$ One could then speculate that the goals of the various bombing campaigns became tailored by the limitations of the technology available; it is no less true of war than politics that it is the art of the possible. Therefore, destruction of civilian morale appeared possible through area bombardment whereas the precise destruction of militarily significant targets was so only rarely or incidentally. ${ }^{80}$

It should also be noted that it is not always the case that aerial bombardment is the least humanitarian weapon available to the commander. War often places an awful burden on commanders to choose between equally unpalatable alternatives. As Lieutenant Colonel Fenrick points out, ${ }^{81}$ in the battle to retake Manila, General MacArthur chose not to bomb the city out of compassion for the inhabitants. He little anticipated the type of fierce house-to-house resistance the Japanese occupiers would offer which resulted in casualties and destruction probably greater even than would have been caused by intensive bombing.

The above discussion goes some way towards explaining why there were no prosecutions for war crimes related to aerial bombardment at Nuremberg or Tokyo. ${ }^{82}$ Despite the retrospective conclusion that the suffering and destruction caused was disproportionate to the goals achieved, similar conduct was engaged in by both sides, with both sides having some foundation to the belief that the bombing would be effective.

\section{POST WORLD WAR II}

The impetus provided by the horrific events of World War II led to the Geneva Conventions, $1949 .^{83}$ The first three conventions deal with the treatment of the wounded, sick, shipwrecked and prisoners of war, while the fourth deals specifically with treatment of civilians in times of war. None of the Conventions deal with restrictions on weapons, ${ }^{84}$ but parts of Convention $I V$ do provide for a very general protection of civilians. For example, Article 14 provides for the establishment of "hospitals and safety zones and localities so organized as to protect from the effects of war, wounded, sick and aged persons, children under fifteen, expectant mothers and mothers of children under

79 See for example, A. Verrier, The Bomber Offensive (B.T. Batsford: 1968).

so Fenrick, supra note 4.

81 Ibid. at 120-21.

2. Levinson, supra note 26 at 125.

83 Convention (l) for the Amelioration of the Condition of Wounded and Sick in Armed Forces in the Field, 75 U.N.T.S. 31; Convention (II) for the Amelioration of the Wounded, Sick and Shipwrecked Members of Armed Forces at Sea, 75 U.N.T.S. 85; Convention (III) Relative to the Treatment of Prisoners of War, 75 U.N.T.S. 135; and Convention (IV) Relative to the Protection of Civilian Persons in Time of War, 75 U.N.T.S. 287. 
seven." 85 Article 15 provides for similar protection in the region where fighting is taking place and Article 16 reaffirms fundamental principles: ${ }^{86}$

The wounded and the sick, as well as the infirm, and expectant mothers, shall be the object of particular protection and respect.

It is remarkable considering the events that had just transpired and the comprehensive nature of the convention in dealing with other cases that so little attention was paid to the means of warfare. Because the Hague Rules of Air Warfare had not been ratified nor adhered to in fact, the most recent laws governing aerial warfare at the conclusion of the Geneva Conventions in 1949 remained the Hague Rules of Land Warfare and the Convention on Bombardment by Navel Forces formulated in $1907 . .^{87}$ Although the principles were still relevant, the rules clearly lacked the requisite specificity to be meaningful to modern means of warfare; the events of both world wars is sad testament to that fact. $^{88}$

\section{PROTOCOL I}

If the events of the two world wars in themselves were not enough to inspire international agreement on the means of warfare, Korea, Vietnam and the Middle East added extra motivation. ${ }^{89}$ With the gradual thawing of the Cold War in the early seventies, and motivated by the activism of the International Committee for the Red Cross, ${ }^{90}$ the United Nations sanctioned attempts by the Red Cross in consultation with representatives from countries around the world to codify the laws of war. The talks were designed to take into account methods and means of warfare, new and unconventional warfare, protection of civilians and the need for the improvement of the extant laws. ${ }^{91}$

A series of meetings during the seventies culminated in 1977 with the adoption of Protocol I dealing with international conflicts and Protocol II dealing with noninternational conflicts. Prior to adoption, the Hague Rules and the Geneva Conventions followed separate strands whereby the rules of warfare were divorced from those concerned with the treatment of the victims of warfare. The Protocols are of great significance because they go a long way toward erasing the distinction and merging the two fields into a coherent whole. ${ }^{92}$

Although Protocol II is of great importance because of its attempt to provide guidelines in the murky area of non-international conflict, it is not of relevance to this paper. Protocol I essentially develops many of the principles found in the Hague Rules of Air

Art 14 in ibid. at 428.

lbid.

lbid. at ix.

lbid.

Ibid. at $\mathrm{x}$ and M. Bothe, K.J. Partsch \& W.A. Solf, eds., New Rules for Victims of Armed Conflicts (Boston: Martinus Nijhoff Publishers, 1982) at 1-3.

Bothe, Partsch, \& Solf, ibid. at 275.

lbid. at 4.

Ibid. at 184 . 
Warfare adding greater specificity and definition to the principles. It also deals head on with aerial bombardment and provides an initiative on the protection of the environment during conflict. ${ }^{93}$ Those articles relevant to the three incidents in the Gulf War mentioned earlier will be reviewed in some detail now before applying them. Part III of Protocol I deals with methods and means of warfare. In it, we find principles of long pedigree in the law of warfare. Article 35 which frames the section, reads in part: ${ }^{94}$

35(1). In any armed conflict, the right of the Parties to the conflict to choose methods or means of warfare is not unlimited.

35(2). It is prohibited to employ weapons, projectiles and material and methods of warfare of a nature to cause superfluous injury or unnecessary suffering.

Implicit in the use of "superfluous" and "unnecessary" is the concept of actions being limited to those of military necessity. Necessity, in turn, is understood to be defined by acts that gain importance from the nature of their objective, a concept that can be seen in subparagraph 1 above. ${ }^{95}$ The clause seems to have the sort of broadness that could render it liable to be completely ignored, for no doubt many, if not all, weapons, on a plain understanding, cause unnecessary suffering. However, commentators have interpreted this in a more restrictive sense, so that weapons like artillery shells or conventional bombs that are designed primarily to destroy objects and so are of much greater explosive power than that required to kill or injure soldiers are not considered illegitimate: ${ }^{96}$

The test is whether the suffering is needless, superfluous, or manifestly disproportionate to the military advantage reasonably expected from the use of the weapon. On the humanitarian side of the equation against which military advantage is to be balanced are such factors as the painfulness or severity of wounds, mortality rates, and the incidence of permanent damage or disfigurement and the feasibility of treatment under field conditions. Neither element of the equation can be taken in isolation.

The balancing of the competing interests of military necessity and humanitarianism can be seen to coalesce in later articles. Article 40 prohibits orders that there shall be no survivors ${ }^{97}$ and Article 41 defines when an enemy is disabled or no longer poses a threat and so ceases to become a legitimate target. ${ }^{98}$ Historical situations of giving no quarter have proven counter-productive in that they usually render the enemy desperate and so more dangerous. They also lead to a tendency to escalate the brutality of the conflict by forcing the enemy to issue similar orders. ${ }^{99}$ The definition of when a person becomes hors de combat is important: ${ }^{100}$

Arts. 35, (3), 55, and 56 are relevant to environmental protection and introduce a new area into the law of warfare. The Gulf War has provided examples of the need for strict regulations in this area; it is a subject warranting detailed study in its own right.

Bothe, supra note 89 at 192.

Ibid. at 195.

lbid. at 196.

Ibid. at 216. This concept is known as giving "no quarter."

Ibid. at 218 - a person in this condition is said to be "hors de combat."

lbid. at 217 .

lbid. at 218. 
Art.4I(2)

A person is hors de combat if:

(a) he is in the power of the Adverse Party:

(b) he clearly expresses an intention to surrender; or

(c) he has been rendered unconscious or is otherwise incapacitated by wounds or sickness, and therefore is incapable of defending himself;

provided that in any of these cases he abstains from any hostile act and does not attempt to escape.

This definition gives substance to the idea that necessity does not require harming a person who is no longer a threat. It provides protection during the difficult interim period between when a person is an active combatant and when he gets the full protection accorded prisoners of war. ${ }^{101}$

Article 42 goes some way towards attempting to clarify the combatant/civilian distinction at a period when many combatants do not fit the traditional mold of being members of an organized, distinct army. For our purposes, it is only important to note its emphasis on the importance of maintaining a basic civilian/combatant distinction even if there remains some uncertainty in marginal cases.

Part IV deals directly with the protection of civilians and so adds emphasis and particularity to Article 43. It provides definitions and imposes obligations on both sides to a conflict with respect to the protection of civilians and so fills the large gaps left in the Hague Rules of Land Warfare and the earlier Geneva Conventions. The basic principle for the section is set out in article $48:^{102}$

In order to ensure respect for and protection of the civilian population and civilian objects, the Parties to the conflict shall at all times distinguish between the civilian population and combatants and between civilian objects and military objectives and accordingly shall direct their operation only against military objectives.

With later provisions, it becomes clear that the Protocol places duties not only on the attacker to respect civilians but also on the defender. For example, Article 49 provides a comprehensive definition of "attack" whereby virtually all acts of violence, whether offensive or defensive, are included. ${ }^{103}$ Article 50 goes on to define "civilians" and in so doing raises two important presumptions: ${ }^{104}$

s.1 ...In case of doubt whether a person is a civilian, that person shall be considered to be a civilian. 
s.3. The presence within the civilian population of individuals who do not come within the definition of civilians does not deprive the population of its civilian character.

Both sections have important ramifications for the status of guerrillas or irregular combatants if captured but they are also extremely important considerations for planners when deciding on legitimate targets. For example, the presence of a few troops home on leave in a suburb would not transform that area into a legitimate target whereas a regiment camping out in the local park would. ${ }^{105}$

Article 51 contains the main substantive provisions for protecting civilians. It reaffirms the prohibitions against making civilian populations the object of attack or causing "Acts or threats of violence the primary purpose of which is to spread terror among the civilian population. ${ }^{106}$ It also prohibits indiscriminate attacks defining indiscriminate attacks as: ${ }^{107}$

(a) those which are not directed at a specific military objective

(b) those which employ a method or means of combat which cannot be directed at a specific military objective; or

(c) those which employ a method or means of combat the effects of which cannot be limited as required by this Protocol;

and consequently, in each such case, are of a nature to strike military objectives and civilians or civilian objects without distinction.

Paragraph 5 goes on to give examples of indiscriminate attacks:

5. Among others, the following types of attacks are to be considered as indiscriminate:

(a) an attack by bombardment by any methods or means which treats as a single military objective number of clearly separated and distinct military objectives located in a city, town, village or other area containing a similar concentration of civilians or civilian objects; and

(b) an attack which may be expected to cause incidental loss of civilian life, injury to civilians, damage to civilian objects, or a combination thereof, which would be excessive in relation to the concrete and direct military advantage anticipated.

This section articulates more clearly the principle of proportionality found in Article $35(2)^{108}$ that has been seen as recurrent in the laws of warfare. It involves the

105 Ibid. at 296. It is of interest to note that Iraq was among the countries that argued for an even wider prohibition that would include acts capable of spreading terror regardless of whether or not they were so intended. Of course discussions took place prior to the current leadership taking power, ibid. at 300. 
assessment of the value of a target compared to what loss could be expected and so sets a somewhat ambivalent standard. ${ }^{109}$ Law is often involved with difficult exercises in trying to determine what constitutes "reasonable" behaviour; it would be difficult to formulate a more specific standard than the one found here without making it grossly unrealistic given our experience of behaviour in war. Paragraph 7 is also of particular importance: ${ }^{110}$

The presence or movements of the civilian population or individual civilians shall not be used to render certain points or areas immune from military operations, in particular in attempts to shield military objectives from attacks or to shield, favour or impede military operations. The Parties to the conflict shall not direct the movement of the civilian population or individual civilians in order to attempt to shield military objectives from attacks or to shield military operations.

This paragraph places a clear obligation on the defending Party to refrain from certain activities and acts as an effective counterbalance to the duty imposed on the attacker to ensure that he does not aim at civilians.

Articles 57 and 58 expand on the specific duties of the parties to the conflict to protect civilians:"'I

57(2) (a) Those who plan or decide upon an attack shall:

(i) do everything feasible to verify that the objectives to be attacked are neither civilians nor civilian objects and are not subject to special protection but are military objectives within the meaning of para. 2 of Art. 52 and that it is not prohibited by the provisions of this Protocol to attack them;

(ii) take all feasible precautions in the choice of means and methods of attack with a view to avoiding, and in any event to minimizing, incidental loss of civilian life, injury to civilians and damage to civilian objects;

(iii) refrain from deciding to launch any attack which may be expected to cause incidental loss of civilian life, injury to civilians, damage to civilian objects, or a combination thereof, which would be excessive in relation to the concrete and direct military advantage anticipated.

(b) An attack shall be cancelled or suspended if it becomes apparent that the objective is not a military one or is subject to special protection or that the attack may be expected to cause incidental loss of civilian life, injury to civilians, damage to civilian objects, or a combination thereof, which would be excessive in relation to the concrete and direct military advantage anticipated. [emphasis added] 
The use of "feasible" in subparagraph 2(a) is an allowance for the exigencies of the battlefield and therefore provides a rule that is capable of being followed. While it places an ethical duty on commanders to do everything in their power to ensure their targets and objectives are rational, it does not impose an impossible standard of certain knowledge. It is also in keeping with the principle of diminishing suffering to the maximum extent possible that a duty is imposed to cease attacking once certainty is gained and it becomes apparent that the target is not legitimate. This rule seems to acknowledge that the awful logic of war often tends to blind soldiers to differing degrees of culpability. Some blood on the hands does not mean that all morality has vanished and any act is justified. Responsibility is clearly placed on those who have the power of decision. ${ }^{12}$ My Lai is informative in this respect because while the soldiers who committed the massacre were rightly brought to trial, those most culpable, the ones whose policies led to the devaluing of Vietnamese life and who gave ambiguous orders and later attempted to suppress the incident, were not. ${ }^{113}$

Article 58 places reciprocal responsibilities on those who have civilians under their control:

The Parties to the conflict shall, to the maximum extent feasible:

(a) without prejudice to Art 19 of the Fourth Convention, endeavour to remove the civilian population, individual civilians and civilian objects under their control from the vicinity of military objectives;

(b) avoid locating military objectives within or near densely populated areas;

(c) take other necessary precautions to protect the civilian population, individual civilians and civilian objects under their control against the dangers from military operations.

Similar to Article 57, Article 58 allows some leeway for practical considerations (a small densely populated country like Israel may be unable to avoid extensive co-location) by including feasibility. It nevertheless provides a clear statement of responsibility of the leaders and occupiers of a country to protect civilians. ${ }^{114}$

Part V of Protocol I gives details on responsibility for violations. For our purposes, Article 85 makes those activities described under Article 51, among others, grave breaches which render violators liable to trial for war crimes. ${ }^{115}$ Also, attacking those who are hors de combat, Article 41, constitutes a grave breach. Article 86 expands on the notion alluded to earlier that Protocol $I$ attempts to place responsibilities on those actors who

\$13 See T. Taylor, supra note 21 and Knoll \& McFadden, eds., supra note 2. Politicians and bureaucratic policy makers are as implicated as soldiers for their roles.

IIt Bothe, Partsch \& Solf, supra note 89 at 374.

IIs lbid. at 509-16. 
have positions of power and influence, regardless of whether they physically committed the breach: ${ }^{116}$

Art.86(2). The fact that a breach of the Conventions or of this Protocol was committed by a subordinate does not absolve his superiors from penal or disciplinary responsibility, as the case may be, if they knew, or had information which should have enabled them to conclude in the circumstances at the time, that he was committing or was going to commit such a breach and if they did not take all possible measures within their power to prevent or repress the breach.

Furthermore, Article 87 imposes a duty on military commanders, possibly from the very lowest levels to the highest, ${ }^{117}$ to prevent breaches of the Protocol, ${ }^{118}$ to educate subordinates regarding the Protocol and the Conventions, and to report or take appropriate disciplinary action upon discovery of a breach. ${ }^{119}$ This places a duty on a state to prosecute its own soldiers upon discovery of breaches. From the provisions quoted it is clear that the drafters of the Protocol have tried to find a balance between overarching humanitarian principles and the exigencies of the battlefield. ${ }^{120}$ The next section discusses whether the rules have proven practical enough to be followed by commanders in the field yet still provide some meaningful protection for non-combatants.

\section{STATUS OF PROTOCOL I}

Some aspects of Protocol I represent a detailed codification of customary international law. The prohibition of giving no quarter, for example, is a principle that has emerged not only in treaties but also as a rule generally accepted by most countries whether signatory or not to a specific international agreement on the subject. Those principles found in Protocol I, then, that have a long lineage in international relations may be determined to have become part of custom and are legally binding on countries that have not satisfied or even participated in the formal international agreements on the law of warfare. From the above discussion, there appears to be ample evidence that principles like unlimited war cannot be resorted to, unnecessary suffering cannot be intentionally inflicted, and acts of violence should be in proportion to the military importance of the objective are part of customary international law. Mere existence of ideas over a long period of time by itself is not sufficient to constitute custom; these principles have been discussed and agreed upon in different fora by many countries indicating that there has existed some consensus among nations over a long period. ${ }^{121}$

Conduct is also important in the formulation of custom. Although it cannot be said that Protocol I has been adhered to in previous conflicts, the Gulf War arguably marks a change. A case could be made that the Coalition campaign exhibited a conscious effort to follow Protocol I almost to the letter. This type of conduct could indicate acceptance

\footnotetext{
$116 \quad$ lbid. at 523

$117 \quad$ lbid. at 528.

$118 \quad$ Art. 87(1), ibid.at 526.

119 Art.87(3), ibid.

120 Fenrick, supra note 4.

121 Schindler \& Toman, supra note 24 at xi.
} 
of the validity of Protocol $I$. It is an important issue because most of the major countries involved in the war participated in the conferences drafting the Protocol but have yet to ratify it despite having signed it thirteen to fourteen years ago. Information from the United Nations indicated that as of February 14, 1991, the U.S.A., U.K., France ${ }^{122}$ and Iraq had not ratified the Protocol. One of the fears surrounding the formulation of the provisions was that whatever was worked out would favour either the technologically advanced countries or, more likely, because of the preponderance of third world countries in attendance, work to the perceived disadvantage of the advanced countries. ${ }^{123}$ In particular, the less advanced countries can rarely afford a significant air force whereas it is a major component of the armed forces of advanced countries. Indeed, the Gulf War and various Arab-Israeli conflicts have proven an effective air force can, in the right circumstances, be decisive. Consequently, many of the provisions found in the Protocol and discussed above appear theoretically to hamper those countries that might rely on air power and lead to recalcitrance on their parts to ratify. Without the ratification of the powerful countries the Protocol risked becoming a dead letter.

The fears were well grounded. Although Article 95 provides that the treaty enters into force six months after two countries had ratified, something that occurred almost immediately upon completion, ${ }^{124}$ ten years later only twelve first world countries had ratified out of seventy-eight in total. None of them were major powers. The situation has improved recently, however, with another eleven first world countries having ratified including Greece, Spain, U.S.S.R., Canada and most recently the Federal Republic of Germany. With one hundred-and-one ratifications from around the world and evidence of conduct in conformity with the Protocol, there are grounds to argue that the Protocol is becoming part of customary international law. It is uncertain to what extent Coalition activity was guided by the belief that member nations were under a legal obligation to act that way or whether their actions merely conformed through coincidence. If the former was the case, and it is difficult to prove either way absent specific declarations by the participants, then international jurisprudence suggests that conduct congruent with perceived legal obligations will provide evidence of customary international law: ${ }^{125}$

Not only must the acts concerned amount to a settled practice, but they must also be such, or be carried out in such a way, as to be evidence of a belief that this practice is rendered obligatory by the existence of law requiring it.... The states concerned must therefore feel that they are conforming to what amounts to a legal obligation.

Condemnation by the Coalition forces of Iraq for various acts as being violations of the laws of war provides some indication of allied beliefs about the legal force of Protocol I. Although many Iraqi actions could be condemned under law about which there can be little doubt, their acts of environmental warfare could only realistically be interpreted as violations of Protocol $I$ as it provides the first codification of laws of war prohibiting such

Although a participant in the conferences, France refused to sign the Protocol.

Bothe, Partsch \& Solf, supra note 89 at 7-8.

Ghana on 28 Feb. 1978 and Libya on 7 June 1978.

North Sea Continental Shelf Cases Federal Republic of Germany v. Denmark and v. Netherlands, [1969] I.C.J. Rep. 3 para. 77. 
actions. ${ }^{126}$ To condemn those acts in legal terms is to acknowledge the force of those laws. It is certainly arguable then that despite non-ratification Protocol $I$ is binding.

Regardless of the accuracy of the above argument, it is more important for this article to test the laws in the abstract for their realism and see if they have the capacity for restraining conflict. For if many of the non-ratifying countries see that it is possible to balance the competing considerations of necessity and humanity, the status of the laws will grow to take on the prestige the Hague rules failed to achieve.

\section{APPLICATION TO THE GULF WAR}

\section{A. GENERAL}

It is quite common for the laws of war to be dismissed, for we cannot help but be reminded of their consistent failure to restrain the brutality of conflict and the savage individual effects that have accompanied wars of all centuries. One reason advanced for their failure has been that they have set impractically high ideals: ${ }^{127}$

Strategy and international political realities are necessary ingredients [in the rules of warfare] which have too often been ignored in the framing of norms by lawyers. Perhaps it is for this reason that the laws of war are in such disarray.

It would appear that the drafters of Protocol I were keenly aware of this problem and tried to establish some practicality in the laws. As R.M. Hare points out, ${ }^{128}$ rules based on prudence have a greater chance of success.

It is also well to bear in mind the particular circumstances of an armed conflict when considering the effectiveness of the rules of war. In some senses, the Gulf War provided ideal conditions that will not necessarily always exist. For example, the heaviest concentration of troops and armour were to be found in terrain offering little natural cover and were, for the most part, far removed from heavily populated areas. For those targets in densely populated areas, the coalition forces had available technology capable of making discriminatory attacks, something unlikely to be available in many conflicts. In addition, the coalition forces possessed both the technology and strength to suppress any activity that would degrade the accuracy of the bombardment. In a conflict between equally matched adversaries of equivalent technological capacity, it is unlikely that a bombardment campaign could be carried on in the same virtually unfettered manner. ${ }^{129}$

Although these considerations should circumscribe any euphoria that laws of war have finally been created that truly constrain conduct in a universal way, they are no longer

See Art. 35(2) and Art. 55 of Protocol I, supra note 3.

Adler, supra note 5 at 282.

Supra note 16 at 59.

See Newsweek (18 Feb. 1991) 49 for the limits of high technology against an equal adversary. The author also draws heavily here on personal knowledge gained through teaching tactical airlift practice and doctrine in the Canadian Forces. 
subject to immediate dismissal for irrelevancy either. It is also important to note that, for the most part, those wealthy and technologically advanced countries that have been most reluctant to ratify the Protocol I are the very ones whose conduct appears at this early point to have most closely conformed to it while the less advanced, poorer country frequently appeared to act in complete disregard of it.

\section{B. THE SCUD ATTACKS}

One of the most egregious violations of Protocol $I$ was the use by Iraq of long range surface-to-surface SCUD missiles to attack Israel, a country that was not participating in the forces allied against Iraq (but whose support for those forces was quite clear). The SCUD missile guidance system is primitive and therefore it cannot be aimed at small, precise targets like military bases, airfields or radar sites. It can, however, be aimed at a large target like a city with some reasonable chances of success. Against Israel, SCUDs appeared to have been launched only at major cities, principally Tel Aviv. The attacks thus seem to be in direct violation of the general prohibition against operations directed against civilian objectives found in Article 48; they also fell under the definition of attack in Article 49 as an act of violence against the adversary, whether in offence or in defence. $^{130}$

The missile attacks also appear to be a prima facie violation of the more specific provisions of Article 51, especially paragraphs 2 and 4 and possibly 6 , if the attacks are interpreted as reprisals for coalition action. Paragraph 2 prohibits making civilians the object of attack or other acts with a primary purpose of spreading terror. Because of the disjunctive nature of Paragraph 2, it does not appear open to the argument that the attacks are excusable because their primary purpose was to split the coalition not terrorize the population. Even if that argument is accepted, it still remains a violation to make civilians the objects of attack regardless of the purpose. Paragraph 4(b) also appears to directly prohibit SCUD type attacks by prohibiting indiscriminate attacks and defining indiscriminate as those attacks which cannot be directed at a specific military objective: ${ }^{131}$

The reference in subpara. 4.b. to methods which cannot be directed at a specific military objective prohibits "blind" weapons which cannot, with any reasonable assurance, be directed against a military objective... using long range missiles [sic] with only a rudimentary guidance system are examples of this type of weapon.

Article 57, which is discussed above as placing a burden on attackers to do everything feasible to avoid violating Article 51, sets the mental element required to establish a violation as a crime. It is unlikely that there would be much merit to any claims that Iraq had done everything feasible to verify its objective were strictly military or had taken 
feasible steps towards minimizing incidental loss of life, provisions which imply all objective reasonableness in assessing whether actions were made with a bona fide attempt to conform to the Protocol.

If there appear to be reasonable grounds within the Protocol for defending the actions, it would be related to the concept that the bombardment constituted a "concrete and direct military advantage." Implicit in Article 57(2)(a) (iii) and (b) is the idea that bombardment is legitimate if loss of civilian life is truly incidental to the attack and proportionate to the benefits from the attack. Certainly the actual losses from the SCUD attacks were surprisingly low. The potential military benefits were also exceeding high, for if Israel had retaliated and the coalition fractured along Arab/non-Arab lines, the war would have taken on an entirely different complexion.

This justification depends on two questionable presumptions, however. First, if the obligations outlined in subparagraph 2(a) can be read as separate rather than complementary and cumulative obligations, subparagraph 2(a) (iii) could potentially be read as overriding the preceding obligations. Satisfaction of this third obligation could be accomplished by emphasizing the important nature of the attack and the low casualties suffered. This textual interpretation is not really sensible though as a logical interpretation from the preamble that "Those who plan or decide upon an attack shall:" and the absence of "or" between clauses suggests that the planner must conform to all of the obligations, not just one of them.

Even if the tenuous argument above could be made out, it is doubtful that continuation of the SCUD attacks against Israel throughout the war could be justified. Article 57(2)(b) orders cancellation of an attack if it becomes apparent that incidental loss of life would be excessive in relation to the concrete and direct military advantage anticipated. With Israeli restraint in the face of attack appearing to strengthen the coalition as time progressed rather than weaken it, the likelihood of any advantage accruing to continued attack let alone the fairly high standard of "concrete and direct military advantage" is hard to imagine. Whatever political advantage in various parts of the Arab world won by the continuance of attacks would not meet the criteria established in Article 57. It therefore appears that the SCUD attacks on Israel were indefensible violations of Protocol $I$.

Because the SCUD attacks appear so clearly to be violations, it must then be asked if the rules operate to the distinct disadvantage of the underdeveloped countries. Arguably, the SCUDs represented one of the few methods Iraq had to defend itself when facing insuperable odds. It is necessary to leave aside the question of the justness of the war at this point, for if the rules unduly hamper self-defence they will not be observed and so become meaningless. A hypothetical situation might suggest an answer. If SCUDs were Kuwait's only means of resisting the Iraqi invasion, it would be hard to imagine universal condemnation or punishment under Protocol $I$ if they fired missiles at Baghdad in the honest belief they could forestall or stop the invasion. It is at this point that the subjective nature of assessing what constitutes a "concrete and direct military advantage" comes into play. If the hypothetical Kuwaiti firings proved futile yet continued to inflict casualties on non-combatants in Baghdad, they would cease to be defensible. This analysis would suggest that the graver a situation is for a country under attack, the wider the latitude it 
will have to defend itself, but that latitude does not become absolute. By making the object of prohibited attacks civilian in nature, an attacked country's right to defend itself through guerilla or resistance movements is not affected, provided their attacks are directed at military objectives and are not of the indiscriminate nature so favoured by terrorists.

\section{THE AMIRIYA BOMB SHELTER}

The Gulf War brought the world up to date on the capabilities of modern weaponry. Despite bombing a large city with an intensity unparalleled in earlier days, ${ }^{132}$ it seemed absolutely remarkable that the bombs were destroying only military targets leaving civilian buildings unscathed and civilian casualties extremely light.

As forecast by one commentator writing just after the Protocol was completed and twelve years before the war: ${ }^{133}$

It would seem that the development of smart bombs guided to their targets by laser or T.V. should facilitate the acceptance of the proposed ban upon area bombardment. Although, these weapons may yet be a weapon only for the technologically advanced states, the same is actually true of the capacity to engage in the costly practice of area bombardment.

The accuracy of the latest generation of bombs and missiles could be seen not only from the select videos displayed by official briefers (and so suspect because of their self-serving nature) but also from the reports broadcast from Baghdad. Yet even pinpoint accuracy in bombing does not preclude tragedy. On 16 February, two bombs fell precisely on their target, completely destroying it. The target turned out to be a bomb shelter and the bodies of approximately 288 civilians were pulled out.

The question of legal liability is a complex one. A number of factors suggest that the bombing was not the result of intentional killing of non-combatants. First, the coalition forces were fighting a media campaign to ensure all of their actions were interpreted as being as moral as possible under the circumstances. ${ }^{134}$ This was necessary to strengthen the initially shaky domestic support and keep the coalition from falling apart. Since Iraq's willingness also to use the media for its own purposes was well understood, declarations of precise bombing contradicted by evidence coming from Baghdad would be even more damning than no declarations at all. So in all likelihood, the bombing of Baghdad was probably genuinely planned to be as precise and accurate as possible. Secondly, absent any media presence, bombing civilians has proven counterproductive in previous campaigns like Vietnam and World War II. As pointed out earlier, it usually tends to consolidate opposition rather than undermine morale. Furthermore, economy of resources would argue against attacking civilian targets. Although coalition forces appear to have been well supplied, it is unlikely that a commander would want to expend some of the at a rate three times higher than the heaviest campaign in Vietnam. 
most valuable munitions in his arsenal and expensive aircraft missions on killing noncombatants. The most plausible explanation would be that the bombing of the shelter was the result of a failure in intelligence, either in assessing the presence of civilians or in overestimating the importance of the target.

Dealing with a failure to discover the presence of civilians first, liability would tend to depend on the nature of the failure. Because the attack and precise weapons were directed at a specific military objective, it could only be considered indiscriminate under Article 51.5(b). This provision, it will be recalled, defines as indiscriminate those attacks which may be expected to cause losses disproportionate to the advantage gained. To understand the concept of expectation, one must move on to Article 57. If, in accordance with subparagraph 2(a)(i), the coalition commander had done "everything feasible to verify the objectives to be attacked are neither civilian nor civilian objects" then his expectation of minimal incidental casualties would be justifiable. It is not possible to determine exactly what "everything feasible" incorporates, but if normal intelligence gathering methods that had proven reliable in the past had been used on this occasion, it is probable that this would meet the required standard. If normal intelligence methods were ignored or not used when available, then it is likely that liability could ensue. Assuming the former scenario, one might sadly conclude that even the most accurate weaponry used in accordance with carefully drafted regulations and with the best of intentions cannot completely eradicate unnecessary suffering in wartime.

The second possibility, that the bombing took place in light of full knowledge of the probable consequences, raises different but related issues. Whereas proportionality was seen to operate in the first situation with respect to the assessment of feasibility, in this latter situation the more conventional understanding of proportionality is engaged. Once again, it is assumed that bombing civilians was not the objective but rather that the shelter housed some military target of importance. It is important to remember that the Protocol does not prohibit the killing of civilians if it occurs incidental to the achievement of a legitimate military objective. However, if deaths, injury, or damage occur excessive in relation to the concrete and direct military advantage anticipated, ${ }^{135}$ the attack is illegal. So the question becomes one of whether or not the target was of such military significance that it warranted killing a large number of civilians. This cannot be determined without the facts; however one must assume in this scenario that it would have to be a target of great importance to merit the killing of civilians. Newsweek reported that Saddam Hussein had been seen by U.S. intelligence sources using the shelter several times in the days preceding the attack, ${ }^{136}$ his presence would undoubtedly make the shelter a target offering a concrete and distinct military advantage.

It can be seen from the discussion of the above scenarios that a commander is not expected to know everything when he makes a decision, but he must make a reasonable effort to discover pertinent information. Furthermore, at all times his decisions must be 
based on the information available interpreted within the guidelines provided by Protocol $I$.

It is also possible that Iraq was attempting to shield an important military site with innocent civilians. Such a callous practice is clearly prohibited by Article 51(7): ${ }^{137}$

The presence or movements of the civilian population or individual civilians shall not be used to render certain points or areas immune from military operations, in particular in attempts to shield military objectives from attacks or to shield, favour or impede military operations. The Parties to the conflict shall not direct the movement of the civilian population or individual civilians in order to attempt to shield military objectives from attacks or to shield military operations.

Regardless of the culpability of Iraq in this matter, however, paragraph 8 goes on to say that the misconduct of one party does not relieve the other of its obligations to take all feasible precautions prior to attack in accordance with Article 57 . The question of liability for the attacker is a distinct matter.

\section{RETREATING SOLDIERS}

The final incident to be reviewed concerns attacks upon retreating forces. There is something intuitively distasteful about attacking somebody who is running away from a fight. This is especially so when those running away have clearly been routed and can no longer be thought of as a threat. Article 40 that prohibits the giving of no quarter emanates from a long tradition of distaste for this practice in the laws of war. As discussed earlier, Article 41 then defines when a person is hors de combat and prohibits attack against him when it is either recognized or should be recognized that he is in that condition. Retreating soldiers are neither in the power of the adverse Party ${ }^{138}$ nor clearly expressing an intention to surrender, ${ }^{139}$ so attacking them would appear legitimate on these two grounds. The final part of the definition suggests a person "unconscious or otherwise incapacitated by wounds or sickness" is hors de combat and not a legitimate target. This too would appear to make retreating soldiers legitimate targets but there is an addition to suggest why unconscious and incapacitated soldiers are excluded from attack: "and, therefore is incapable of defending himself." If an expansive, purposive interpretation of this is made, then soldiers in civilian cars could perhaps not be considered capable of defending themselves, especially when attacked by fighter bombers.

If this admittedly tenuous argument can be made out, it would still be open in the case of the Gulf War to argue that those escaping soldiers killed were collateral to the main and legitimate purpose of destroying Iraqi armour. This once again engages the principle of proportionality and whether the benefit gained from destroying armoured vehicles justified killing soldiers who no longer posed a threat. This sort of issue illustrates the awful decisions a commander in war must make and the difficulty of formulating a law 
that makes allowance for the exigencies of battle without sacrificing humanitarian principles completely.

\section{CONCLUSION}

Three incidents have been chosen from the Gulf War not to draw a specific conclusion respecting possible violations of international law, but rather to examine the way in which the modern laws of war could be applied and to illustrate the extreme difficulties of legislating in this area. It is a hopeful sign that modern technology can be seen from certain conduct in the war to coalesce rather than outdate the most recent laws. It is significant that the bombing of the shelter stands out in the war as an exceptional incident rather than a normal or routine one. It is curious then to observe that modern technology, if used in accordance with Protocol I, can, by discriminating between military and civilian personnel and objectives, limit the suffering in war, for the most part, to the combatants.

Nothing in the above should be construed as approval of war that can be limited to inflicting casualties on combatants alone. It must be reiterated that the goals of the laws of war are not designed to eradicate war, rather they now exist in a fairly primitive stage to act as a normative guide to preserve some element of humanity in the midst of chaos. They are predicated on the recognition that until civilization devises some methods of resolving problems without force, it is necessary to limit the suffering that accompanies war as much as possible.

Protocol I appears to be capable of practical application. If the enforcement provisions, characteristically the most problematic area of international law, can be engaged to bring the most egregious offenders to trial for war crimes, it will be seen as the next important step forward. As long as nations remain committed to maintaining the same level of sovereignty over their affairs as they currently do, it is unlikely that any consistent application of the laws can be made. Once some sacrifice is made by nations to allow the laws to evolve to the next stage of development and enforcement is widely understood to be effective, experience refining and applying the laws of war in the abstract will prove invaluable. 